\title{
Fungsionalisasi UU No. 23 Tahun 2004 \\ dalam Penanggulangan Tindak Pidana dalam Lingkup Rumah Tangga \\ (Analisis Putusan No. 98/Pid.B/2007/PN.YK dan Putusan No. 273/Pid.B/2010/PN.SLMN.)
}

\author{
Anny Retnowati \\ Fakultas Hukum Universitas Atma Jaya Yogyakarta \\ Jl. Mrican Baru 2855281 Yogyakarta \\ annyretnowati@gmail.com
}

\begin{abstract}
This research was conducted to answer two problems: first, the counter measures for criminal acts in households, especially the acts related to two decrees, those are Decree No. 98/Pid.B/2007/PN.YK and Decree No. 273/Pid.B/2010/PN.SLMN. Second, the settlement taken related to those two decrees. The research used normative method. The findings show that: first, criminal acts in household scope especially ones related to Decree No. 98/Pid.B/2007/PN.YK and Decree No. 273/Pid.B/2010/PN.SLMN are countered by functionalize Article 41 verse (1) of Law No. 23 of 2004 on Domestic Violence Regulation. Second, the settlement of those two cases is conducted using repressive legal process that can prove that those two defendants had convincingly and legally conducted criminal act in form of violence against their wives. Consequently, District Court of Yogyakarta decided six-month imprisonment, and District Court of Sleman decided one-year imprisonment for the defendants.
\end{abstract}

Key words : Functionalization, Law No. 23, 2004, physical violence crime

\begin{abstract}
Abstrak
Penelitian ini dilakukan untuk menjawab dua permasalahan: pertama, penanggulangan tindak pidana dalam lingkup rumah tangga, khususnya yang berkaitan dengan dua putusan, yakni putusan No. 98/ Pid.B/2007/PN.YK dan putusan No. 273/Pid.B/2010/PN.SLMN. Kedua, penyelesaian yang ditempuh terhadap kedua putusan tersebut. Penelitian ini menggunakan metode normatif. Hasil penelitian menunjukkan bahwa: pertama, tindak pidana dalam lingkup rumah tangga khususnya yang berkaitan dengan putusan No. 98/Pid.B/2007/PN.YK dan putusan No. 273/Pid.B/2010/PN.SLMN ditanggulangi dengan memfungsio-nalisasikan Pasal 41 ayat (1) UU No. 23 Tahun 2004 tentang PKDRT. Kedua, penyelesaian kedua kasus tersebut dilakukan melalui proses hukum represif yang dapat membuktikan bahwa kedua terdakwa telah secara sah dan meyakinkan melakukan tindak pidana kekerasan fisik terhadap isteri mereka masing-masing. Oleh karena itu, PN Yogyakarta menjatuhkan enam bulan penjara dan PN Sleman menjatuhkan satu tahun penjara kepada masing-masing terdakwa.
\end{abstract}

Kata Kunci : Fungsionalisasi, UU No. 23 Tahun 2004, tindak pidana kekerasan fisik 


\section{Pendahuluan}

Di dalam Penjelasan Umum Undang-Undang No. 23 Tahun 2004 tentang Penghapusan Kekerasan Dalam Rumah Tangga (UU PKDRT) dinyatakan bahwa keutuhan dan kerukunan rumah tangga yang bahagia, aman, tenteram, dan damai merupakan dambaan setiap orang dalam rumah tangga. Negara Republik Indonesia adalah Negara yang berdasarkan Ketuhanan Yang Maha Esa dijamin oleh Pasal 29 Undang-Undang Dasar 1945. Dengan demikian, setiap orang dalam lingkup rumah tangga dalam melaksanakan hak dan kewajibannya harus didasari oleh agama. Hal ini perlu terus ditumbuhkembangkan dalam rangka membangun keutuhan rumah tangga.

Untuk mewujudkan keutuhan dan kerukunan tersebut, sangat tergantung pada setiap orang dalam lingkup rumah tangga, terutama kadar kualitas perilaku dan pengendalian diri setiap orang dalam lingkup rumah tangga tersebut. Keutuhan dan kerukunan rumah tangga dapat terganggu jika kualitas dan pengendalian diri tidak dapat dikontrol, yang pada akhirnya dapat terjadi kekerasan dalam rumah tangga sehingga timbul ketidakamanan atau ketidakadilan terhadap orang yang berada dalam lingkup rumah tangga tersebut.

Untuk mencegah, melindungi korban, dan menindak pelaku kekerasan dalam rumah tangga, negara dan masyarakat wajib melaksanakan pencegahan, perlindungan, dan penindakan pelaku sesuai dengan falsafah Pancasila dan UUD 1945. Negara berpandangan bahwa segala bentuk kekerasan, terutama kekerasan dalam rumah tangga, adalah pelanggaran hak asasi manusia dan kejahatan terhadap martabat kemanusiaan serta bentuk diskriminasi. Pandangan negara tersebut didasarkan pada Pasal 28 UUD 1945 beserta perubahannya.

Pasal 28G ayat (1) UUD 1945 menentukan bahwa "Setiap orang berhak atas perlindungan diri pribadi, keluarga, kehormatan, martabat dan harta benda yang berada di bawah kekuasaannya, serta berhak atas rasa aman dan perlidungan dari ancaman ketakutan untuk berbuat dan tidak berbuat sesuatu yang merupakan hak asasi". Pasal 28H ayat (2) UUD 1945 menentukan bahwa "Setiap orang berhak mendapat kemudahan dan perlakuan khusus untuk memperoleh kesempatan dan manfaat yang sama guna mencapai persamaan dan keadilan". Perkembangan dewasa ini menunjukkan bahwa tindak kekerasan secara fisik, psikis, seksual, dan penelantaran rumah tangga pada kenyataannya terjadi sehingga dibutuhkan perangkat hukum yang memadai untuk menghapus kekerasan dalam rumah tangga. 
Karena memuat ketentuan pidana (Pasal 44 s/d Pasal 53), maka UU PKDRT termasuk hukum pidana administrasi, khususnya di bidang kesejahteraan sosial. Menurut Barda Nawawi Arief, ${ }^{1}$ hukum pidana administrasi pada hakekatnya merupakan perwujudan dari kebijakan menggunakan hukum pidana sebagai sarana untuk menegakkan/melaksanakan hukum administrasi. Jadi, merupakan bentuk "fungsio-nalisasi/operasionalisasi/instrumentalisasi hukum pidana di bidang administrasi".

Selain itu, menurut Sudarto ${ }^{2}$, hukum pidana mempunyai fungsi khusus yaitu melindungi kepentingan hukum terhadap perbuatan yang hendak memperkosanya (Rechtsgutersschutz) dengan sanksi berupa pidana yang sifatnya lebih tajam jika dibandingkan dengan sanksi yang terdapat pada cabang hukum lainnya. Kepentingan-kepentingan hukum (benda-benda hukum) ini boleh dari orang seorang, dari badan atau dari kolektiva, misalnya masyarakat, negara dsb. Sanksi yang tajam itu dapat mengenai harta benda, kehormatan, badan dan kadang-kadang nyawa seseorang yang memperkosa benda-benda hukum itu. Dapat dikatakan bahwa hukum pidana itu memberi aturan-aturan untuk menanggulangi perbuatan jahat.

Berkaitan dengan fungsi hukum pidana administrasi sebagaimana diutarakan di atas, maka penulis ingin mengetahui bagaimana UU PKDRT difungsionalisasikan, khususnya dalam penanggulangan tindak pidana dalam lingkup rumah tangga yang pernah diproses di PN Yogyakarta dan PN Sleman serta bagaimana kinerja penegak hukum di wilayah hukum Pengadilan Negeri (PN) Yogayakarta dan PN Sleman dalam upaya penanggulangannya dengan menggunakan perangkat hukum yang ada guna memberikan efek jera dalam rangka mengeliminir tindak pidana dalam lingkup rumah tangga di Propinsi Daerah Istimewa Yogyakarta (DIY) di masa yang akan datang dan sekaligus memberikan rasa keadilan bagi masyarakat dengan melakukan penelitian yang berjudul “Fungsionalisasi UU No. 23. Tahun 2004 dalam Penanggulangan Tindak Pidana dalam Lingkup Rumah Tangga dengan Pendekatan Kasus (Studi tentang Putusan No. 98/Pid.B/2007/PN.YK dan Putusan No. 273/ Pid.B/2010/PN.SLMN)."

\footnotetext{
${ }^{1}$ Barda Nawawi Arief, Kapita Selekta Hukum Pidana, Bandung, Penerbit PT. Citra Aditya Bakti, 2003, hlm.15-16. ${ }^{2}$ Sudarto, Hukum Pidana I, Semarang,Yayasan Sudarto Fakultas Hukum Undip, 1990, hlm. 12.
} 


\section{Rumusan Masalah}

Setelah menguraikan latar belakang masalah, maka dapat dirumuskan dua permasalahan pokok, yakni: Pertama, bagaimana penanggulangan tindak pidana dalam lingkup rumah tangga khususnya dalam perkara No. 98/Pid.B/2007/PN.YK dan No.273/Pid.B/2010/PN.SLMN? Kedua, bagaimana penyelesaian perkara tindak pidana dalam lingkup rumah tangga No. 98/Pid.B/2007/PN.YK dan No.273/ Pid.B/2010/PN.SLMN?

\section{Tujuan Penelitian}

Fokus penelitian akan diarahkan pada dua tujuan utama, yakni: Pertama, untuk mengetahui dan menganalisis fungsionalisasi UU PKDRT dalam penanggulangan tindak pidana dalam lingkup rumah tangga khususnya dalam perkara No. 98/Pid.B/ 2007/PN.YK dan No.273/Pid.B/2010/PN.SLMN. Kedua, untuk mengetahui dan menganalisis proses penyelesaian perkara tindak pidana dalam lingkup rumah tangga No. 98/Pid.B/2007/PN.YK dan No.273/Pid.B/2010/PN.SLMN.

\section{Metode Penelitian}

Penelitian ini merupakan penelitian hukum normatif dengan menggunakan pendekatan kasus sebagai cara untuk mengetahui bagaimana bahan-bahan hukum yang mengatur tentang masalah kekerasan dalam lingkup rumah tangga difungsionalisasikan di wilayah hukum PN Yogyakarta dan Pengadilan Negeri Sleman oleh para penegak hukum yang berwenang dalam penanggulangan 'tindak pidana kekerasan fisik dalam lingkup rumah tangga', khususnya dalam putusan perkara No. 98/Pid.B/2007/PN.YK dan No.273/Pid.B/2010/PN.SLMN.

Data yang berhasil dikumpulkan dengan menggunakan teknik studi kepustakaan (library research) serta ditunjang dengan penelitian lapangan (field research) dianalisis dengan menggunakan analisis kualitatif ${ }^{3}$, yaitu analisis yang didasarkan atas nilai, kualitas dan keadaan data yang diperoleh. Dengan kata lain pencarian kebenaran dalam penelitian ini didasarkan dan diukur dengan kualitas, nilai dan keadaan data yang bersangkutan. Analisis kualitatif dalam penelitian harus mendapat

${ }^{3}$ F. Sugeng Istanto, "Teknik dan Metode Penelitian Hukum", disampaikan dalam "Pelatihan Penelitian Intensif 
kebenaran dengan mengukur data yang diperoleh dengan unsur-unsur ketentuan hukum yang berlaku.

Penarikan kesimpulan dalam penelitian ini dilakukan dengan menggunakan metode deduksi. Menurut F. Sugeng Istanto, ${ }^{4}$ metode deduksi adalah suatu cara mengungkap kebenaran dengan mengukur kesesuaian antara suatu spesies dengan genusnya. Di dalam pembahasan mengenai penerapan hukum positif ini yang merupakan genus adalah UU PKDRT yang berlaku umum sedangkan speciesnya adalah peristiwa 'kekerasan fisik dalam lingkup rumah tangga' yang merupakan realisasi dari ketentuan hukum yang berlaku umum tersebut.

\section{Hasil Penelitian dan Pembahasan}

G. Widiartana ${ }^{5}$ yang mengutip Rita Selena Kalibongso, menyatakan bahwa pada umumnya masyarakat beranggapan bahwa lingkungan di luar rumah lebih berbahaya dibandingkan dengan di dalam rumah. Anggapan tersebut bisa jadi terbentuk karena kejahatan yang banyak diungkap dan dipublikasikan adalah kejahatan yang terjadi di luar lingkungan rumah. Sedangkan rumah dianggap sebagai tempat yang aman bagi anggota keluarga dan orang-orang yang tinggal di dalamnya, dapat berinteraksi dengan landasan kasih, saling menghargai dan menghormati. Masyarakat tidak menduga bahwa rumah dapat menjadi tempat yang paling mengerikan bagi anggota keluarga. Kekerasan, apapun bentuk dan derajad keseriusannya dapat terjadi di dalam rumah di antara orang-orang yang seharusnya saling mengasihi dan menghargai. Rumah yang seharusnya menjadi tempat untuk saling berbagi dan berlindung ternyata justru menjadi sumber penyebab terjadinya penderitaan.

Menurut Leo Kleden, ${ }^{6}$ kekerasan itu mempunyai banyak bentuk: pelecehan seksual, perdagangan perempuan, komersialisasi tubuh perempuan dalam pornografi, perbudakan seksual dan penganiayaan dalam keluarga, pemerkosaan dan pembantaian perempuan dalam perang, pembunuhan atau pembuangan bayi perempuan, pelacuran yang dipaksakan, pemotongan alat vital, insest, ancaman

\footnotetext{
${ }^{4}$ F. Sugeng Istanto, Penelitian Hukum, Cet. Ke-1, Yogyakarta, C.V. GANDA, 2007, hlm. 36.

${ }^{5}$ G. Widiartana, Ide Keadilan Restoratif pada Kebijakan Penanggulangan Kekerasan dalam Rumah Tangga dengan Hukum Pidana, Ringkasan Disertasi, Semarang, Program Doktor Ilmu Hukum UNDIP, 2011, hlm. 1.

${ }^{6}$ Leo Kleden, “Menyikapi Kekerasan terhadap Perempuan (Sebuab Tijanan Teologis dan Perspektif Katolik)" dalam Benyaimin Y. Bria (ed), Kekerasan Terbadap Perempuan dan Bagaimana Menyikapinya (Kajian Teologis dan Yuridis), Yogyakarta,
} 
dan terror, pembungkaman dan perampasan hak-hak asasi. Kalau kita membuat analisis secara teliti maka menjadi jelas bahwa tindakan kekerasan ini menyeruak dalam berbagai aspek kehidupan: sosial, ekonomi, pendidikan, moral dan agama.

Sementara itu menurut Neil Allan Weiner dkk. (1990) sebagaimana dikutip Aroma Elmina Martha ${ }^{7}$, tindakan kererasan dalam rumah tangga (KDRT) yang diakui sebagai problem sosial ini awalnya adalah tindakan kekerasan terhadap anak (abuse of children). Definisi ini hanya terbatas pada penganiayaan dan penyiksaan, namun perkembangannya diperluas ke dalam bentuk kekurangan gizi, kekerasan seksual, penelantaran pendidikan, kesehatan yang tidak terurus, dan kekerasan secara mental. Perkembangan ruang lingkup selanjutnya adalah bentuk penganiayaan terhadap istri. Diakui bahwa kekerasan terhadap istri menjadi problem masyarakat secara bersama, sehingga ruang lingkup kejahatan ini termasuk juga kekerasan seksual, perkosaan dalam rumah tangga dan pronografi.

Hasbianto sebagaimana dikutip Meiyenti ${ }^{8}$ menyatakan bahwa KDRT merupakan masalah sosial yang serius, yang kurang mendapat tanggapan dari masyarakat. Pertama, KDRT mempunyai ruang lingkup yang relatif tertutup dan terjaga ketat privacy-nya karena persoalannya terjadi dalam keluarga. Kedua, KDRT dianggap wajar karena diyakini bahwa memperlakukan istri sekehendak suami merupakan hak suami sebagai pemimpin dan kepala rumah tangga. Ketiga, KDRT terjadi dalam lembaga yang legal, yaitu perkawinan. Kenyataan inilah yang menyebabkan minimnya respon masyarakat terhadap keluh kesah para istri yang mengalami persoalan KDRT dalam perkawinan. Akibatnya mereka memendam persoalan itu sendirian, tidak tahu bagaimana menyelesaikannya, dan semakin yakin pada anggapan yang keliru, yaitu suami memang mengontrol istri.

Aroma Elmina Martha ${ }^{9}$ selanjutnya menjelaskan bahwa sebagai perbandingan, sejarah perkembangan kekerasan suami terhadap istri pada awalnya berasal dari common law Inggris (tahun 1896), yang memberikan kekuasaan dan hak kepada suami untuk mendidik/memberi disiplin kepada istri dengan cara menggunakan alat tongkat yang disebut dengan istilah "Rule of thumb", dengan cara suami boleh memukul istri dengan tongkat yang tidak lebih besar dari ibu jari. Kekerasan rumah tangga ini semula dianggap sebagai persoalan privat, namun dalam

\footnotetext{
${ }^{7}$ Aroma Elmina Martha, Perempuan, Kekerasan dan Hukum, Yogyakarta, UII Press, 2003, hlm.37-38.

${ }^{8}$ Sri Meiyenti, Kekerasan terhadap Perempuan dalam Rumah Tangga, Yogyakarta, Kerja sama Ford Foundation dan PSKK UGM, 1999, hlm. 4.
} 
perkembangannya persoalan rumah tangga ini menjadi persoalan umum yang terbuka untuk dibicarakan siapa saja.

Tingginya kasus kekerasan terhadap perempuan telah membuka mata sejumlah aktivis perempuan yang sejak 1997 berjuang keras dan akhirnya berhasil dengan disahkannya UU PKDRT pada 22 September 2004. Adanya undang-undang ini menunjukkan bahwa permasalahan KDRT merupakan permasalahan krusial yang dari waktu ke waktu masih menunjukkan jumlah dan intensitasnya, meskipun disadari bahwa hal tersebut merupakan pelanggaran terhadap hak asasi dan kebebasan fundamental perempuan.

Pasal 1 angka 1 UU PKDRT menyebutkan bahwa dalam undang-undang ini yang dimaksud dengan Kekerasan dalam Rumah Tangga adalah setiap perbuatan terhadap seseorang terutama perempuan yang berakibat timbulnya kesengsaraan atau penderitaan secara fisik, seksual, psikologis, dan/atau penelantaran rumah tangga termasuk ancaman untuk melakukan perbuatan, pemaksanaan, atau perampasan kemerdekaan secara melawan hukum dalam lingkup rumah tangga.

Pasal 2 menentukan bahwa lingkup rumah tangga dalam undang-udang ini meliputi: a. suami, istri, dan anak; b. orang-orang yang mempunyai hubungan keluarga dengan orang sebagaimana dimaksud pada huruf a karena hubungan darah, perkawinan, persusuan, pengasuhan, dan perwalian, yang menetap dalam rumah tangga; dan/atau c. orang yang bekerja sebagaimana dimaksud huruf c dipandang sebagai anggota keluarga dalam jangka waktu selama berada dalam rumah tangga yang bersangkutan. Orang yang bekerja sebagaimana dimaksud huruf c dipandang sebagai anggota keluarga dalam jangka waktu selama berada dalam rumah tangga yang bersangkutan.

Pasal 3 menentukan bahwa penghapusan kekerasan dalam rumah tangga dilaksanakan berdasarkan asas: a. penghormatan hak asasi manusia; b. keadilan dan kesetaraan jender; c. nondiskriminasi; dan d. perlindungan korban.

Pasal 4 menentukan bahwa penghapusan kekerasan dalam rumah tangga bertujuan: a. mencegah segala bentuk kekerasan dalam rumah tangga; b. melindungi korban kekerasan dalam rumah tangga; c. menindak pelaku kekerasan dalam rumah tangga; dan d. memelihara keutuhan rumah tangga yang harmonis dan sejahtera.

Sedangkan Pasal 5 menentukan bahwa setiap orang dilarang melakukan kekerasan dalam rumah tangga terhadap orang dalam lingkup rumah tangganya, dengan cara: a. kekerasan fisik; b. kekerasan psikis; c. kekerasan seksual; atau d. 
penelantaran rumah tangga. Keempat jenis kekerasan dalam rumah tangga ini diatur secara rinci dalam ketentuan pidana Pasal 44 s.d. Pasal 53.

Landasan hukum bagi hak perempuan yang bersifat menyeluruh ialah Konvensi Penghapusan Segala Bentuk Diskriminasi terhadap Perempuan (Convention on Elimination of All Forms of Dscrimination Against Women) yang diadopsi oleh Majelis Umum PBB pada 18 Desember 1961 setelah 20 negara meratifiksi konvensi tersebut. Indonesia meratifikasi Konvensi dengan UU No. 7 Tahun 1984 tentang Pengesahan Konvensi Mengenai Penghapusan Segala Bentuk Kekerasan Terhadap Wanita. Konvensi tersebut disebut juga Konvensi Wanita, atau Konvensi Perempuan, atau Konvensi Cedaw.

Menurut Sumijati Sahala ${ }^{10}$, Konvensi ini merupakan konvensi yang penting untuk dilaksanakan oleh negara sebagai peserta konvensi, karena Konvensi Wanita yang telah menjadi komitmen negara-negara di dunia menekankan kesetaraan antara perempuan dan laki-laki (equality and equity), walaupun dalam konvensi diakui adanya perbedaan biologis, yaitu perbedaan fungsi reproduksi dan perbedaan gender yang merupakan konstruksi sosial. Namun bila perbedaan-perbedaan tersebut akan merugikan perempuan, maka dalam pelaksanaannya negara harus memperhatikan beberapa prinsip yang dianut konvensi, yaitu prinsip persamaan, prinsip non diskriminasi dan prinsip kewajiban negara.

Pasal 15 Konvensi Wanita yang sudah diratifikasi dengan UU No. 7 Tahun 1984 menentukan: (1) negara-negara peserta wajib memberikan kepada wanita persamaan hak dengan pria di muka hukum. (2) negara-negara peserta wajib memberikan kepada wanita: a. hak dan tanggung jawab yang sama sebagai orangua, terlepas dari status perkawinan mereka, dalam urusan-urusan yang berhubungan dengan anak-anak mereka, dalam semua kasus kepentingan anak-anaklah yang diutamakan; b. dalam urusan-urusan sipil, kecakapan yang sama dengan pria dan kesempatan yang sama untuk menjalankan kecakapan tersebut; c. khususnya memberikan kepada wanita hak yang sama untuk menandatangani kontrak-kontrak dan mengurus harta benda, serta d. wajib memberikan perlakuan sama pada semua tingkatan prosedur di muka hakim dan sidang peradilan (courts and tribunals).

Berkaitan dengan ketentuan Pasal 15 ayat (1) Konvensi Wanita bahwa negara peserta wajib memberikan kepada wanita persamaan hak dengan pria di muka

${ }^{10}$ Sumijati Sahala, Mainstream Gender dan Upaya Pemberdayaan Perempuan di Bidang Hukum, Jakarta, Badan pembinaan Hukum Nasional, Departemen Kehakiman dan Hak Asasi Manusia, 2001, hlm. 13-17. 
hukum, Ridwan Mansyur ${ }^{11}$ menjelaskan bahwa dari pengalaman persidangan terhadap perempuan korban kekerasan berbasis gender, ditemukan bahwa sistem hukum belum memberikan perlindungan hukum yang cukup bagi perempuan korban. Dengan kata lain sistem hukum belum berperspektif perempuan. Banyak kasus perempuan yang berbasis gender yang gagal diproses sampai pengadilan karena kesulitan pembuktian, putusan yang belum memenuhi rasa keadilan, selain itu banyak perempuan yang memilih untuk mendiamkan kekerasan dan perkara lainnya yang dialaminya karena takut ancaman fisik, psikis, seksual dan kehilangan sumber penghasilan.

Tidak adanya perlakuan khusus pada proses pemeriksaan perkara seringkali membuat korban menjadi korban untuk sekian kalinya. Minimnya pengetahuan hakim tentang perspektif perempuan membuat korban menjadi tidak nyaman dan trauma ketika bersinggungan dengan sistem hukum kita. Untuk meminimalisir trauma yang dialami perempuan korban kekerasan dalam setiap proses peradilan, untuk menghapus segala bentuk kekerasan berbasis gender dan untuk memberikan perlindungan hukum yang cukup bagi perempuan korban kekerasan berbasis gender dalam mencari keadilan, hakim harus bersikap progresif dan proaktif dalam mencari keadilan.

\section{Penanggulangan Tindak Pidana dalam Lingkup Rumah Tangga}

\section{Putusan Perkara No. 98/Pid.B/2007/PN.YK}

"DEMI KEADILAN BERDASARKAN KETUHANAN YANG MAHAESA". Mengingat dan memperhatikan Pasal 44 ayat (1) UU No. 23 Tahun 2004 serta peraturan-peraturan lain yang bersangkutan dengan perkara ini, ${ }^{12}$ MENGADILI: 1. Menyatakan bahwa terdakwa Manto (bukan nama sebenarnya), telah terbukti secara sah dan menyakinkan bersalah melakukan tindak pidana "kekerasan fisik dalam lingkup rumah tangga." 2. Menjatuhkan pidana oleh karena itu dengan pidana penjara kepada terdakwa selama 6 (enam) bulan. 3. Menetapkan lamanya terdakwa ditahan dikurangkan seluruhnya dari pidana yang dijatuhkan. 4. Menetapkan agar terdakwa tetap ditahan. 5. Memerintahkan supaya barang bukti berupa: a. Visum

\footnotetext{
${ }^{11}$ Ridwan Mansyur, "Persidangan Perkara Perspektif Gender", dalam Achie Sudiarti Luhulima (ed), Bahan Ajar Tentang Hak Perempuan, UU No. 7 Tabun 1984 tentang Pengesaban Konvensi Mengenai Penghapusan Segala Bentuk Diskriminasi Terhadap Wanita, Edisi Pertama, Jakarta, Yayasan Obor Indonesia, 2007, hlm. 325-329.

${ }^{12}$ Putusan Perkara No. 98/Pid.B/2007/PN.YK, Yogyakarta, 6 Juni 2007 , hlm. 9-10..
} 
Et Repertum No. 331/3381/RSUD/XII/2006 tanggal 24 Desember 2006 yang dibuat oleh Dr. Ending Wirandini dari Rumah sakit Umum Daerah Yogyakarta; b. Fotokopy Duplikat Kutipan akta nikah No. DUP.N/PW.01/12/2006/ tanggal 6 Agustus 2006; Tetap terlampir dalam berkas perkara; 1 . Membebankan terdakwa untuk membayar biaya perkara sebesar Rp. 1000,- (seribu rupiah).

Demikianlah dijatuhkan putusan ini pada hari Rabu, tanggal 6 Juni 2007 dalam rapat permusyawaratan Majelis Hakim Pengadilan Negeri Yogyakarta yang terdiri dari: Zubaidah Wahab, S.H., sebagai Ketua Majelis, Sapawi, S.H., M.H. dan Djatmiko MH Girsang, S.H., M.Hum, masing-masing sebagai Hakim Anggota, yang diucapkan dalam sidang terbuka untuk umum, oleh Ketua Majelis tersebut dengan dihadiri Hakim-Hakim Anggota tersebut dan dibantu oleh Mira Puspitasari, S.H., Panitera Pengganti, dihadiri oleh Sugito, S.H., Jaksa Penuntut Umum serta terdakwa tersebut.

\section{Putusan Perkara No. 273/Pid.B/2010/PN.SLMN}

“DEMI KEADILAN BERDASARKAN KETUHANAN YANG MAHA ESA". Menginat Pasal 41 ayat (1) UU No, 23 Tahun 2004, UU No. 8 Tahun 1981 tentang KUHAP, serta pasal-pasal lain dari peraturan perundang-undangan yang bersangkutan, ${ }^{13} \mathrm{MEN}$ G A D I L I: 1. Menyatakan Terdakwa Yanto (bukan nama sebenarnya) terbukti secara sah dan meyakinkan bersalah melakukan tindak pidana 'kekerasan fisik dalam lingkup rumah tangga'; 2. Menjatuhkan pidana oleh karena itu kepada terdakwa Yanto dengan pidana penjara selama 1 (satu) tahun; 3. Menetapkan masa penahanan yang telah dijalani oleh terdakwa dikurangkan seluruhnya dari pidana yang dijatuhkan; 4. Menetapkan barang bukti berupa: Sebilah bambu panjang kurang lebih 1 (satu) meter dimusnahkan; 5. Membebankan biaya perkara kepada terdakwa sebesar Rp. 2000., (dua ribu rupiah); 6. Menetapkan terdakwa tetap berada dalam tahanan.

Demikianlah dijatuhkan putusan ini pada hari: Rabu, tanggal 30 Juni 2010 dalam rapat permusyawaratan Majelis Hakim Pengadilan Negeri Sleman yang terdiri dari: Hery Supriyono S.H., M.Hum., sebagai Ketua Majelis, Putut Sri Sunarko, S.H., M.H. dan Erna Indrawati, SH., masing-masing sebagai Hakim Anggota, yang diucapkan dalam sidang terbuka untuk umum, oleh Ketua Majelis tersebut dengan dihadiri Hakim-Hakim Anggota tersebut dan dibantu oleh Sutijo, sebagai Panitera Pengganti pada Pengadilan Negeri Sleman, serta dihadiri oleh Tri Widhi Astuti, SH., Jaksa Penuntut Umum pada Kejaksaan Negeri Sleman serta Terdakwa.

\footnotetext{
${ }^{13}$ Putusan Perkara No. 273/Pid.B/2010/PN.SLMN, Yogyakarta, 23 Juni 2012, hlm. 13-14.
} 
Berdasarkan hasil penelitian sebagaimana diuraikan di atas, terlihat bahwa ‘Kekerasan fisik dalam lingkup rumah tangga' baik dalam perkara No. 98/Pid.B/ 2007 / NP.YK maupun dalam perkara No. 273/Pid.B/2010/PN.SLMN dapat ditanggulangi dengan mengfunsionalisasikan Pasal 41 ayat (1) UU PKDRT. Kekerasan fisik dalam lingkup rumah tangga tersebut merupakan kekerasan domestik dalam keluarga. Menurut Syakrani dan Sandra Bhakti Mafriana ${ }^{14}$, secara teoretis kekerasan domestik dalam keluarga bisa diamati dalam tiga aras hubungan, marital relation, parental relation, dan sibling relation. Dalam analisis gender, kekerasan suami terhadap istri (marital relation), yang berbentuk makian, kemarahan dan pemukulan menjadi isu yang lebih dominan. Analisis kekerasan domestik tidak dapat dilepaskan dari telaah masalah kekerasan terhadap perempuan pada umumnya. Kekerasan fisik dan emosional terhadap perempuan merupakan fenomena yang terjadi sejak zaman dulu dan terus terjadi sampai sekarang. Oleh karena itu praktik ini sudah membudaya, bahkan kekerasan itu sudah setua umur manusia.

Dalam perkara No. 98/Pid.B/2007/PN.YK. ${ }^{15}$ kekerasan fisik telah dilakukan oleh terdakwa Manto terhadap Yanti isterinya (bukan nama sebenarnya) pada hari Kamis tanggal tanggal 21 Desember 2006 sekitar pukul 09.30 WIB, di Kalangan UH II V/689 A, Pandeyan, Umbulharjo, Yogyakarta. Terdakwa telah melakukan pemukulan terhadap saksi korban yaitu isterinya dengan menggunakan tangan kosong sebanyak dua kali mengenai bagian tangan sebelah kanan dan kiri serta menendang mengenai kepala bagian muka yang mengakibatkan saksi korban menderita luka memar di atas mata sebelah kiri dan pipi sebelah kiri serta terdapat luka memar di lengan tangan kanan dan kiri bagian atas dan pada bagian pinggul sebalah kanan sesuai Visum Et Repertum No. 331/3381/RSUD/XII/2006 yang dikeluarkan oleh Rumah Sakit Umum Daerah Yogyakarta 24 Desember 2006. Perbuatan ini dilakukan ketika terdakwa berada di kamar bersama saksi korban dan minta cerai kepada isteri terdakwa dan kemudian isteri terdakwa minta uang sebesar Rp. 500.000,- (lima ratus ribu rupiah) untuk biaya cerai, namun terdakwa marah lalu memukul saksi korban.

Sedangkan dalam perkara No. 273/Pid.B/2010/PN.SLMN ${ }^{16}$ kekerasan fisik telah dilakukan oleh terdakwa Yanto terhadap saksi korban yaitu Avi isterinya

${ }^{14}$ Syakrani dan Sandra Bhakti Marfiana, Kaji Tindak Penanggulangan Kekerasan dalam Rumab Tangga, Yogyakarta, Kerja sama Ford Foundation dan PSKK UGM, 2005, hlm. 5.

${ }^{15}$ Putusan No. 98/Pid.B/2007/PN.YK, Op. Cit., hlm. 2-3. 
(bukan nama sebenarnya) pada Rabu 17 Maret 2010, sekitar jam 06.30 WIB bertempat di Guyangan: 216 RT. 03/07, Nogotirto Gamping Sleman. Terdakwa telah melakukan pemukulan terhadap saksi korban dengan menggunakan tangan kosong dan sebilah bambu panjang kurang lebih 1 (satu) meter yang mengakibatkan saksi korban mengalami memar-memar di bagian tangan kanan, pinggang, paha, lutut kaki kanan dan kaki kiri sesuai dengan Visum Et Repertum yang dikeluarkan oleh Rumah Sakit Umum Daerah Sleman Nomor: 440/86/2010, 24 Maret 2010.

Perbuatan tersebut dilakukan terdakwa karena merasa kesal dengan saksi korban yang sehari-harinya bekerja sebagai pemandu karaoke di Boshe VVIP club tidak pulang ke rumah pada hari Selasa tanggal 16 Maret 2010 dan terdakwa merasa kecewa dengan saksi korban karena tidak bisa berhubungan suami isteri dengan saksi korban. Terdakwa meminta saksi korban berhenti dari pekerjaannya dan akhirnya saksi korban menuruti permintaan terdakwa tersebut. Tetapi tiba-tiba terdakwa justru meminta saksi korban untuk bekerja kembali namun saksi korban tidak mau menuruti permintaan terdakwa tersebut sehingga terjadi pertengkaran mulut antara terdakwa dengan saksi korban yang berujung pada kekerasan fisik yang dilakukan terdakwa terhadap saksi korban.

Kekerasan yang dilakukan oleh suami terhadap isteri dalam dua kasus di atas termasuk dalam kekerasan fisik yang menjadi perhatian serius $\mathrm{PBB}$, karena pandangan PBB sebagaimana dikutip Meiyenti ${ }^{17}$ menyatakan bahwa tindak kekerasan terhadap perempuan harus diartikan sebagai kekerasan yang bersifat fisik, seksual dan psikologis. Kekerasan itu terjadi: 1. di dalam rumah tangga; termasuk pemukulan, penyalahgunaan seksual terhadap anak perempuan di dalam rumah tangga, perkosaan di dalam perkawinan, praktek tradisi yang membahayakan perempuan, kekerasan berupa eksploitasi seks; 2. Di dalam masyarakat; termasuk perkosaan, pelecehan seksual, intimidasi di tempat kerja, di tempat pendidikan, dan di tempat lain, dan perdagangan perempuan (trafficking women); dan 3. Memaksa untuk melacur dilakukan atau diperbolehkan oleh negara; dimana pun terjadi.

Sedangkan menurut Niken Savitri, ${ }^{18}$ kekerasan terhadap perempuan lebih spesifik lagi sering dikategorikan sebagai kekerasan gender. Hal ini disebabkan kekerasan terhadap perempuan seringkali diakibatkan adanya ketimpangan gender karena adanya

\footnotetext{
${ }^{17}$ Meiyenti, Op., Cit., hlm. 4.

${ }^{18}$ Niken Savitri, HAM Perempuan, Kritik Teori Hukum Feminis terhadap KUHP, Cetakan Pertama, Bandung, PT Refika Aditama, 2008, hlm. 49-50.
} 
relasi kekuasaan yang tidak seimbang. Hal ini antara lain dapat terefleksikan dari kekuasaan kekerasan dalam rumah tangga yang lebih sering dilakukan oleh orang yang memiliki kekuasaan lebih kepada orang yang lebih lemah dalam rumah tangga yang lebih sering dilakukan oleh laki-laki terhadap perempuan daripada sebaliknya. Kekerasan berbasis gender ini memberikan penekanan khusus pada akar permasalahan kekerasan yang dilakukan terhadap perempuan, yaitu antara pelaku dan korbannya terdapat relasi gender dimana di dalam posisi dan perannya tersebut, pelaku mengendalikan dan korban adalah orang yang dikendalikan melalui tindakan tersebut.

Ketimpangan dalam relasi gender ini sebenarnya sudah disadari masyarakat internasional sehingga Deklarasi Hak Asasi Manusia (DUHAM) tahun 1948 sudah meliputi persamaan hak laki-laki dan perempuan. Namun menurut Achie Sudiarti Luhulima, ${ }^{19}$ sejak awal berdirinya PBB pada tahun 1945, disadari oleh masyarakat dunia bahwa HAM perempuan memerlukan pengaturan khusus. Sikap ini didasarkan atas kenyataan di seluruh dunia, yang sampai kini masih berlanjut, yaitu: 1. hampir semua masyarakat di dunia ditandai sikap yang menganggap bahwa perempuan lebih rendah kedudukan dan nilainya dibanding laki-laki. Sumbangan perempuan bagi kehidupan keluarga dan masyarakat, maupun sumbangan di dunia kerja atau bagi pertumbuhan ekonomi, masih sangat kurang diakui dan dihargai. Hal ini menyebabkan bahwa perempuan pada umumnya kurang atau sama sekali tidak berperan dalam proses pengambilan keputusan dalam keluarga maupun dalam masyarakat. Akses pada pendidikan lebih kurang dari laki-laki, sehingga pilihan kerja bagi perempuan juga sangat terbatas dan pendapatan perempuan sering lebih rendah dari laki-laki untuk pekerjaan sama atau sama nilainya; 2. Sangat banyak dan jauh lebih banyak jumlah perempuan miskin, pekerja perempuan yang tidak berketrampilan, dan yang menjadi korban kekerasan, penganiayaan dan perdagangan, dibandingkan dengan laki-laki; 3. Sumber pelanggaran HAM perempuan dan anak-anak perempuan sering ditemukan dalam keluarga sendiri, yaitu tempat dimana mereka pertama-tama mengetahui dan mengalami hidup sebagai warga kelas dua dan laki-laki sebagai warga kelas satu.

Menurut Wini Tamtiari, ${ }^{20}$ kekerasan terhadap perempuan di Indonesia dapat menimpa perempuan dari berbagai kelompok maupun kelas sosial, tidak terkecuali

${ }^{19}$ Achie Sudiarti Luhulima, "Hak Perempuan dalam Deklarasi Universal Hak. Asasi Manusia (DUHAM)", dalam Achie Sudiarti Luhulima (ed), Bahan Ajar Tentang Hak Perempuan, UU No. 7 Tabun 1984 tentang Pengesahan Konvensi Mengenai Penghapusan Segala Bentuk Diskriminasi terhadap Wanita, Edisi Pertama, Jakarta, Yayasan Obor Indonesia, 2007, hlm. 41-42.

${ }^{20}$ Wini Tamtiari, Awig-Awig, Melindungi Perempuan dari Kekerasan dalam Rumah Tangga?, Yogyakarta, Kerja sama 
perempuan yang tinggal di desa, di kota, kaya, miskin, berpendidikan tinggi maupun yang tidak berpendidikan dapat mengalami bentuk kekerasan, baik secara fisik, sosial, ekonomi, seksual maupun psikologis.

\section{Penyelesaian Perkara Tindak Pidana dalam Lingkup Rumah Tangga No. 98/Pid.B/ 2007/PN.YK dan No.273/Pid.B/2010/PN.SLMN}

Sebagaimana telah dijelaskan di atas, 'Kekerasan fisik dalam lingkup rumah tangga' baik dalam perkara No. 98/Pid.B/2007/NP.YK maupun dalam perkara No. 273/Pid.B/ 2010/PN.SLMN dapat ditanggulangi dengan mengfungsionalisasikan Pasal 41 ayat (1) UU PKDRT. Fungsionalisasi Pasal 41 ayat (1) tersebut didasarkan pada proses penyelesasian perkara tindak pidana dalam lingkup rumah tangga yang menyimpulkan bahwa kedua terdakwa telah secara sah dan meyakinkan terbukti bersalah melakukan tindak pidana yang memenuhi unsur-unsur Pasal 41 ayat (1) UU PKDRT.

Pasal 41 ayat (1) UU PKDRT menentukan: (1) Setiap orang yang melakukan perbuatan kekerasan fisik dalam lingkup rumah tangga sebagaimana dimaksud dalam Pasal 5 huruf a dipidana dengan pidana penjara paling lama 5 (lima) tahun atau denda paling banyak Rp 15.000.000,00 (lima belas juta rupiah).

Dari konstruksi pasal tersebut di atas, ada dua unsur yang harus dibuktikan oleh Majelis hakim dalam penyelesaian kedua perkara tersebut, yaitu: 1. barang siapa; 2. melakukan perbuatan kekersan fisik dalam lingkup rumah tangga.

Unsur 'barang siapa' (Hij Die) dimaksudkan sebagai kata yang menyatakan kata ganti orang sebagai subyek hukum pidana yang akan mempertanggung jawabkan secara pidana dalam perkara-perkara tersebut, yaitu yang identitasnya sebagaimana dimaksud oleh Pasal 155 ayat (1) jo Pasal 197 ayat (1) huruf b KUHAP dan telah diuraikan oleh Jaksa Penuntut Umum dalam surat dakwaannya, yaitu terdakwa Manto dalam perkara No. 98/Pid.B/2007/PN.YK. dan terdakwa Yanto dalam perkara No.273/Pid.B/ /2010/PN.SLMN.

Unsur 'melakukan perbuatan kekerasan fisik dalam lingkup rumah tangga', bahwa yang dimaksud dengan kekerasan fisik di sini adalah sebagaimana yang dirumuskan di dalam Pasal 6 UU PKDRT, yaitu kekerasan fisik sebagaimana dimaksud dalam Pasal 5 huruf a adalah perbuatan yang mengakibatkan rasa sakit, jatuh sakit atau luka berat.

Bahwa yang dimaksud dengan lingkup rumah tangga di sini adalah sebagaimana yang tertuang dalam Pasal 2 yang meliputi: 1 . suami, istri dan anak; 2 . 
orang-orang yang mempunyai hubungan keluarga dengan orang sebagimana dimaksud pada huruf a karena hubungan darah, perkawinan, persusuan, pengasuhan dan perwalian yang menetap dalam rumah tangga dan/atau 3. orang yang bekerja membantu rumah tangga dan menetap dalam rumah tangga tersebut.

Dari fakta-fakta hukum yang terungkap di persidangan dalam perkara No. 98/ Pid.B/2007/PN.YK. di PN Yogyakarta telah ternyata bahwa saksi korban Yanti adalah isteri terdakwa Manto, sedangkan dalam perkara No.273/Pid.B/ /2010/ PN.SLMN. di PN Sleman telah ternyata bahwa saksi korban Avi adalah isteri terdakwa Yanto. Oleh karena itu Majelis Hakim PN Yogyakarta dalam perkara No. 98/Pid.B/2007/PN.YK. berpendapat bahwa perbuatan kekerasan fisik yang dilakukan oleh terdakwa Manto adalah kekerasan di dalam lingkup keluarga, dan Majelis Hakim PN Sleman dalam No.273/Pid.B/ /2010/PN.SLMN. berpendapat bahwa perbuatan kekerasan fisik yang dilakukan oleh terdakwa Yanto adalah kekerasan di dalam lingkup keluarga. Maka Majelis hakim baik dalam perkara No. 98/Pid.B/2007/PN.YK. di PN Yogyakarta maupun dalam perkara No.273/Pid.B/ /2010/PN.SLMN. di PN Sleman berpendapat bahwa unsur ini telah terpenuhi.

Adanya kedua unsur tersebut telah dapat dibuktikan oleh Majelis Hakim. Berdasarkan fakta-fakta yang terungkap di persidangan dan keterangan para saksi dan terdakwa, serta dihubungkan pula dengan barang bukti yang diajukan di persidangan, maka Majelis hakim telah mendapat cukup bukti yang sah dan menyakinkan menurut hukum, bahwa para terdakwa telah terbukti bersalah melakukan tindak pidana: 'kekerasan fisik dalam lingkup rumah tangga' sebagaimana dimaksud dalam Pasal 41 ayat (1) UU PKDRT.

Majelis hakim juga tidak menemukan hal-hal yang dapat menghilangkan pertanggungjawaban para terdakwa baik alasan pemaaf maupun alasan pembenar dalam kedua perkara tersebut, oleh karena itu para terdakwa harus dinyatakan bersalah dan kepada para terdakwa harus dijatuhi pidana sesuai dengan kadar kesalahannya. Namun demikian sebelum menjatuhkan putusan, Majelis hakim juga mempertimbangkan hal-hal yang memberatkan dan meringankan para terdakwa.

Hal-hal yang memberatkan dalam perkara No. 98/Pid.B/2007/PN.YK ${ }^{21}$ adalah: - Perbuatan terdakwa dilakukan terhadap isterinya yang seharusnya dilindungi oleh terdakwa; - Perbuatan terdakwa mengakibatkan isteri terdakwa luka-luka.

${ }^{21}$ Putusan No. 98/Pid.B/2007/PN.YK, Op. Cit., hlm. 9. 
Hal-hal yang meringankan²2: - Terakwa mengakui terus terang akan perbuatannya sehingga memperlancar jalannya persidangan; - Terdakwa menyesali perbuatannya dan berjanji tidak akan mengulanginya lagi; - Terdakwa mempunyai tanggungan anak yang masih kecil-kecil.

Berdasarkan pertimbangan terhadap hal-hal yang meringankan dan memberatkan tersebut, maka pidana yang dijatuhkan kepada terdakwa berupa pidana penjara selama enam (enam) bulan dikurangi masa penahanan yang telah dijalani oleh terdakwa, oleh Majelis Hakim PN Yogyakarta ${ }^{23}$ dipandang telah memenuhi rasa keadilan dan kepatutan. Putusan ini lebih ringan dari tuntutan Jaksa Penuntut Umum yang menuntut pidana penjara selama 10 (sepuluh) bulan potong masa tahanan.

Sedangkan Hal-hal yang memberatkan dalam perkara No. 273/Pid.B/2010/ PN.SLMN ${ }^{24}$ adalah: Perbuatan terdakwa dilakukan terhadap orang yang seharusnya dilindungi oleh terdakwa. Hal-hal yang meringankan ${ }^{25}$ - Terdakwa bersikap sopan di persidangan; - Terdakwa mengaku terus terang sehingga memperlancar jalannya persidangan;- Terdakwa belum pernah dihukum;

Berdasarkan pertimbangan terhadap hal-hal yang meringankan dan memberatkan tersebut, maka pidana yang dijatuhkan kepada terdakwa berupa pidana penjara selama 1 (satu) tahun dikurangi masa penahanan yang telah dijalani oleh terdakwa, oleh Majelis Hakim PN Sleman ${ }^{26}$ dipandang telah memenuhi rasa keadilan dan kepatutan. Putusan ini pun lebih ringan dari tuntutan Jaksa Penuntut Umum yang menuntut pidana penjara selama 1 (satu) tahun 6 (enam) bulan potong masa tahanan.

Bila kedua putusan tersebut dihubungkan dengan ketentuan Pasal 41 ayat (1) UU PKDRT yang memuat ketentuan pidana penjara pidana penjara paling lama 5 (lima) tahun atau denda paling banyak Rp 15.000.000,00 (lima belas juta rupiah), maka menurut peneliti kedua putusan tersebut sudah layak dan pantas dijatuhkan kepada para terdakwa, karena peneliti setuju dengan pertimbangan Majelis hakim yang memberatkan para terdakwa yaitu bahwa perbuatan para terdakwa dilakukan terhadap isteri mereka yang seharusnya dilindunginya dan dicintainya, namun sebaliknya para terdakwa melakukan kekerasan sehingga isteri mereka menderita

\footnotetext{
${ }^{22}$ Ibid.

${ }^{23}$ Ibid.

${ }^{24}$ Putusan No.: 273/Pid.B/2010/PN.SLMN, Op. Cit., hlm. 12.

${ }^{25}$ Ibid.
} 
luka-luka sebagaimana dijelaskan dalam dua Visum Et Repertum untuk kedua perkara tersebut.

\section{Penutup}

Berdasarkan pembahasan yang telah diuraikan di depan, maka penelitian ini dapat menyimpulkan dua hal, yakni: Pertama, penanggulangan tindak pidana dalam lingkup rumah tangga, khususnya tindak pidana 'kekerasan fisik dalam lingkup rumah tangga' dalam perkara No. 98/Pid.B/2007/PN.YK dan No.273/Pid.B/2010/ PN.SLMN dilakukan dengan mengfungsionalisasikan Pasal 41 ayat (1) UU PKDRT yang mengandung dua unsur yaitu: barangsiapa dan melakukan perbuatan kekerasan fisik dalam lingkup rumah tangga. Kedua, penyelesaian perkara tindak pidana dalam lingkup rumah tangga dalam perkara No. 98/Pid.B/2007/PN.YK dan No.273/Pid.B/2010/PN.SLMN dilakukan dalam suatu proses tindakan hukum represif yang dapat membuktikan bahwa perbuatan para terdakwa memang memenuhi kedua unsur Pasal 41 ayat (1) UU PKDRT sehingga para terdakwa yang telah terbukti secara sah dan meyakinkan melakukan 'tindak pidana 'kekerasan fisik dalam lingkup rumah tangga' layak dijatuhi pidana.

\section{Daftar Pustaka}

Achie Sudiarti Luhulima (ed), Bahan Ajar tentang Hak Perempuan, UU No. 7 Tahun 1984 tentang Pengesahan Konvensi Mengenai Penghapusan Segala Bentuk Diskriminasi terhadap Wanita, Edisi Pertama, Jakarta, Yayasan Obor Indonesia, 2007.

Elmina Martha, Aroma, Perempuan, Kekerasan dan Hukum, Yogyakarta, UII Press, 2003.

Nawawi Arief, Barda, Kapita Selekta Hukum Pidana, Bandung, Penerbit PT. Citra Aditya Bakti, 2003.

Sugeng Istanto, F., "Teknik dan Metode Penelitian Hukum", disampaikan dalam "Pelatihan Penelitian Intensif Terfokus", Yogyakarta, Lembaga Penelitian UAJY, 10 Juli 1999. , Penelitian Hukum Cet. Ke-1, C.V. Ganda,Yogyakarta, , 2007.

Widiartana, G., Ide Keadilan Restoratifpada Kebijakan Penanggulangan Kekerasan dalam Rumah Tangga dengan Hukum Pidana, Ringkasan Disertasi, Semarang, Program Doktor Ilmu Hukum UNDIP, 2011.

Y. Bria, Benyaimin, (ed), Kekerasan terhadap Perempuan dan Bagaimana Menyikapinya (Kajian Teologis dan Yuridis), Yogyakarta, Yayasan Pustaka Nusantara, 2003. 
Savitri, Niken, HAM Perempuan, Kritik Teori Hukum Feminis terhadap KUHP, Cetakan Pertama, Bandung, PT Refika Aditama, 2008.

Meiyenti, Sri, Kekerasan terhadap Perempuan dalam Rumah Tangga, Yogyakarta, Kerja sama Ford Foundation dan PSKK UGM, 1999.

Sudarto, Hukum Pidana I, Semarang,Yayasan Sudarto Fakultas Hukum Undip, 1990.

Sahala, Sumijati, Mainstream Genderdan Upaya Pemberdayaan Perempuan di Bidang Hukum, Jakarta, Badan pembinaan Hukum Nasional, Departemen Kehakiman dan Hak Asasi Manusia, 2001.

Syakrani dan Sandra Bhakti Marfiana, Kaji Tindak Penanggulangan Kekerasan dalam Rumah Tangga, Yogyakarta, Kerja sama Ford Foundation dan PSKK UGM, 2005.

Wini Tamtiari, Awig-Awig, Melindungi Perempuan dari Kekerasan dalam Rumah Tangga?, Yogyakarta, Kerja sama Ford Foundation dan PSKK UGM, 2005.

Putusan No. 98/Pid.B/2007/PN.YK, Yogyakarta, PN Yogyakarta, 6 Juni 2007.

Putusan Perkara No. 273/Pid.B/2010/PN.SLMN, Yogyakarta, PN Sleman, 23 Juni 2010. 